\title{
EFL teacher burnout and self-assessed language proficiency: exploring possible relationships
}

\author{
Akram Nayernia ${ }^{*}$ (D) and Zareh Babayan
}

\footnotetext{
* Correspondence: nayernia@iust.ac. ir; a.nayernia@gmail.com Iran University of Science and Technology, Tehran, Iran
}

\begin{abstract}
Although teacher burnout has drawn the attention of many researchers, there is little empirical evidence for the contribution of non-native English language teachers' language proficiency level to their experience of burnout. To address this significant gap, the present study examined the relationship between English as a foreign language (EFL) teachers' self-assessed language proficiency and their experience of burnout. Research has indicated that personal resources of teachers can function as protectors against their experience of burnout. Thus, it was assumed that investigating how EFL teachers' level of burnout can be reduced through language proficiency as a personal resource can cast a new light on the role of personal resources in reducing teachers' experience of burnout. To this end, data were collected from 110 Iranian EFL teachers who were teaching in private language institutes through the Maslach Burnout Inventory - Educator Survey and Iranian EFL Teacher Self-Reported Language Proficiency Scale. The correlational analysis revealed that language proficiency had a significant negative relationship with the emotional exhaustion and depersonalization dimensions and a significant positive relationship with the personal accomplishment dimension of burnout. The results of regression analysis also indicated that, except for the reading subskill, all the other proficiency subskills were the best predictors of the different dimensions of burnout. Based on the findings of the current study, some pedagogical implications and research suggestions were also proposed.
\end{abstract}

Keywords: EFL, Teacher burnout, Self-assessment, Teacher proficiency

\section{Introduction}

Teachers' well-being and influence has been regarded as significant to and influential in students' learning and education. According to Maslach and Leiter (1999), teachers' "well-being and their contribution to student education should be a primary objective of educational leaders" (p. 303). However, less attention has been directed to teachers than learners in English Language Teaching (ELT) studies (Akbari 2008).

Burnout is regarded as a symptom of lack of professional well-being (e.g., Klusmann et al. 2008) of individuals who do people-oriented professions such as teaching (Byrne 1999; Maslach and Leiter 1999). Nevertheless, it is revealed that among the professions who provide human and social services, teachers experience the highest levels of burnout (Chiron et al. 2010; Grayson and Alvarez 2008; Hakanen et al. 2006; Kinman et al. 2011; Kokkinos 2007; Skaalvik and Skaalvik 2010). Furthermore, teacher burnout as an 
experience of depletion of emotional resources, depersonalization of students, and lack of personal accomplishment has substantial impacts on teachers' effective professional functioning (e.g., Klusmann et al. 2008; Maslach 2003; Maslach et al. 2001).

From a theoretical perspective, burnout emerges because of misfit between job demands and individual resources to cope with those demands (Maslach 2003; Maslach et al. 2001). Correspondingly, different scholars have studied not only situational factors, such as misbehavior of students and supervisory support, but also teachers' individual factors, such as their sense of self-efficacy and professional knowledge, which can expose them to or buffer them from psychological pressure, stress, and burnout (Dicke et al. 2015; Durr et al. 2014; Lauerman and König 2016; Skaalvik and Skaalvik 2010). In other words, the more individual resources and competence (e.g., professional knowledge), the better teachers would overcome the difficulties of teaching profession and thus less probable to experience the psychological strain of burnout (e.g., Dicke et al. 2014, 2015; Durr et al. 2014; Klusmann et al. 2008; Lauerman and König 2016; Schwarzer and Hallum 2008).

In English as a second/foreign language (ESL/EFL) literature, target language proficiency plays a crucial role in teachers' competency and learners' learning. English language proficiency as an aspect of EFL teachers' competency and subject knowledge (Richards 2017; Richards et al. 2013) has generally been identified as one of the most fundamental characteristics of a good English teacher in ESL/EFL education (Braine 2010; Llurda 2005). Furthermore, due to the fast spread of English language around the world, non-native English-speaking teachers (NNESTs) have increased vastly in number (Eslami and Fatahi 2008), and consequently, most of the teachers who teach English in EFL contexts are NNESTs. On the other hand, several researchers have stressed the importance of high English language proficiency for teachers (e.g., Butler 2004; Elder and Kim 2014; Nakata 2010) because different aspects of teachers' teaching (e.g., confidence) and learners' learning (e.g., motivation) are influenced by teachers' language proficiency either positively or negatively (Butler 2004). Additionally, research has indicated that target language proficiency of EFL teachers can influence their teaching efficacy (Chacón 2005; Choi and Lee 2016). However, despite its importance, insufficient language proficiency is often regarded as one of the biggest challenges and impediments that non-native EFL teachers confront in their employment, teaching, and professional development (Brain 1999; Chen and Goh 2011; Hiver 2013).

Taking the above theoretical framework and empirical evidence into account, investigating the contribution of non-native EFL teachers' language proficiency to their burnout experience can cast a new light on the role of individual resources in reducing teachers' experience of burnout. While several attempts have been made to investigate the contribution of EFL teachers' individual characteristics to their burnout experience (e.g., Akbari and Tavassoli 2011; Kulavuz-Onal and Tatar 2017; Vaezi and Fallah 2011), few if any studies have stressed and discussed the role of developed or inadequate language proficiency of non-native EFL teachers as protector against or contributor to stress and ultimately burnout respectively (Akbari and Eghtesadi 2017; Khani and Mirzaee 2014). Despite these studies' invaluable contribution to scientific research and educational implications, they have not directly investigated the association between non-native EFL teachers' language proficiency as an individual resource and the 
psychological strain of burnout by adopting a quantitative research methodology. Hence, the current study attempts to address this gap in the EFL context by investigating the relationship between non-native EFL teachers' language proficiency and their experience of burnout. Based on the findings of the current research, some pedagogical implications and research suggestions will be proposed for EFL teacher educators. In particular, the present study aims to find answers to the following research questions:

1. Is there any statistically significant relationship between EFL teachers' self-assessed language proficiency and their experience of the three dimensions of burnout?

2. If so, which of the subskills of language proficiency can best predict the different dimensions of burnout among EFL teachers?

\section{Literature review}

\section{Teacher burnout}

Burnout is a psychological syndrome which entails long time response to work stressors (Maslach 2003). The construct was first developed into psychology by Freudenberger (1974) as a state of exhaustion that emerges from working too hard without paying attention to one's own needs (Byrne 1999). Later, Maslach and Jackson (1986) defined it as "a syndrome of emotional exhaustion, depersonalization, and reduced personal accomplishment that can occur among individuals who do 'people work' of some kind" (p. 1). However, Pines and Aronson (1988) define it as a state of physical, emotional, and mental exhaustion which can emerge because of prolonged exposure to emotionally demanding situations. Furthermore, burnout can be regarded as the result of coping with work-related stress unsuccessfully for a long time (Jennett et al. 2003). In teacher burnout, emotional exhaustion refers to when teachers feel emotionally exhausted and depleted. Depersonalization or cynicism refers to when teachers become callous and indifferent toward their students and their job. Eventually, reduced personal accomplishment refers to when teachers feel themselves ineffective or incompetent in helping their students learn (Maslach and Jackson 1981; Maslach et al. 1996; Maslach et al. 2001).

\section{Factors influencing teacher burnout}

Research has indicated that environmental and individual factors can lead to the emergence of burnout among teachers. In a comprehensive study among 2249 teachers in Norway, Skaalvik and Skaalvik (2010) examined relations among self-efficacy, external control, burnout, job satisfaction, and contextual factors by means of structural equation modeling (SEM). Concerned with the contribution of contextual factors to burnout aspects, they found that relations to parents and time pressure are the strongest predictors of depersonalization and emotional depletion respectively. Further, they revealed a weak but significant relationship between discipline problems of students' behavior and emotional exhaustion and depersonalization dimensions of burnout. Investigating the relationship between Iranian EFL teachers' emotional intelligence and burnout, Vaezi and Fallah (2011) found a significant negative relationship between these two constructs. In another study, Skaalvik and Skaalvik (2009) disclosed that teacher autonomy and supervisory support are negatively related to all three dimensions of burnout. In another 
investigation, Ghanizadeh and Ghonsooly (2014) studied attribution, self-regulation, and burnout among EFL teachers by employing SEM. In doing so, they found that of all attributions, only the institutional supervision was a significant predictor of teacher burnout. Additionally, they revealed that self-regulation has a negative significant association with teacher burnout. In regard to the relationship between self-efficacy and burnout, Skaalvik and Skaalvik (2007) revealed a strong association between teacher self-efficacy and teacher burnout. In another study among 119 in-service teachers, Lauerman and König (2016) studied the contribution of general pedagogical knowledge and self-efficacy to teachers' experience of burnout. Correspondingly, they found that general pedagogical knowledge can function as a protector against teachers' burnout experience. More specifically, they found that general pedagogical knowledge, as an aspect of teachers' professional competence, can predict emotional exhaustion and diminished personal accomplishment dimensions indirectly via teacher self-efficacy. However, they revealed that general pedagogical knowledge can predict depersonalization dimension of burnout both directly and indirectly via teacher self-efficacy.

\section{Teachers' target language proficiency}

Several definitions have been proposed for "the construct of proficiency or competence" (Butler 2004, p. 251) by different scholars (e.g., Bachman and Palmer 1996; Chomsky 1965; Hymes 1972). Accordingly, Chomsky (1965), as a formal linguist, conceptualizes competence as rule-governed structures of language and calls it grammatical competence or linguistic competence. From a sociolinguistic perspective, Hymes (1972) focuses on the notion of communicative competence which consists of knowledge and the ability to use language in a way which is socially appropriate in a particular context. Furthermore, Bachman and Palmer (1996) conceptualize it as a multidimensional construct which entails organizational knowledge, grammatical knowledge, textual knowledge, pragmatic knowledge, functional knowledge, and sociolinguistic knowledge. However, several scholars have contended that defining and measuring the open notion of language proficiency and consequently teachers' language proficiency are difficult and demanding (Canh and Renandya 2017; Lantolf and Frawley 1988).

Teachers' target language proficiency has been considered as a significant part of language teacher competence and as an influential factor in student learning (e.g., Andrews 2007; Butler 2004; Cheng and Wang 2004; Richards 2015). Richards (2015) claims that language proficiency significantly affects how well a teacher can teach a second language. Furthermore, EFL teachers should possess an advanced level of target language proficiency because they are considered as the main source of input which is an essential principle for effective instructed language learning (Canh and Renandya 2017; Ellis 2005; Kim and Elder 2008). On the other hand, teachers who are less proficient could encounter difficulties in correcting the errors of language learners (Farrell and Richards 2007). In a qualitative study in Vietnam, Canh and Renandya (2017) examined the extent to which EFL teachers' target language proficiency and their competence to use it can create learning opportunities for the learners. Accordingly, they concluded that English language teachers should possess not only advanced level of general English language 
proficiency but also classroom English language proficiency for effective learning and teaching.

Language proficiency is influential in EFL teachers' efficacy (Chacón 2005; Choi and Lee 2016; Eslami and Fatahi 2008; Tsang 2017). For instance, Chacón (2005) studied the efficacy beliefs and self-reported English language proficiency of EFL teachers in Venezuela. In doing so, she found a positive relationship between teachers' self-perceived language proficiency and sense of efficacy in student engagement and instructional strategies. In a similar vein, Eslami and Fatahi (2008) studied the relations between self-efficacy, instructional strategies, and self-assessment of language proficiency among 40 high school EFL teachers. Accordingly, they found a positive relationship between self-reported level of language proficiency and feelings of self-efficacy. Moreover, they found that teachers who have higher self-efficacy are more inclined to use communicative-oriented strategies.

Several researchers have addressed the insufficient target language proficiency of non-native English speaker teachers (e.g., Reves and Medgyes 1994; Samimy and Brutt-Griffler 1999). In doing so, Reves and Medgyes (1994) studied 216 native and non-native EFL teachers in different countries. Accordingly, they disclosed that $84 \%$ of the non-native teachers feel incompetent with regard to speaking, listening, writing, pronunciation, and vocabulary. In another study, Samimy and Brutt-Griffler (1999) indicated that $72 \%$ of their participants who were non-native pre-service teachers consider their insufficient English language proficiency as an impediment to their teaching. In an investigation in EFL context of Korea, Taiwan, and Japan, Butler (2004) studied elementary teachers' self-perceived level of target language proficiency and the minimum level of proficiency that they felt was necessary to teach English at the elementary school level. Accordingly, the researcher revealed that teachers assessed their proficiency in speaking and writing at lower levels than in reading and listening. More specifically, teachers felt significance gaps between their perceived language proficiency and the necessary level for teaching.

\section{Inadequate teacher language proficiency and possible strains}

Research has indicated that insufficient target language proficiency of NNESTs can contribute to the emergence of various disorders among them. Correspondingly, insufficient language proficiency of non-native foreign language teachers has been identified as a cause of anxiety among them (e.g., Horwitz 1996). With regard to the subskills of language proficiency, Bekleyen (2009) studied foreign language listening anxiety among EFL teacher candidates in Turkey. Accordingly, she found that the teachers had high level of foreign language listening anxiety and they related it to their insufficient listening proficiency and inadequate training. Focusing on relations between anxiety and burnout, the above findings may be regarded meaningful since several scholars disclosed convincing evidence that burnout syndrome is gradual and strongly linked with the anxiety disorder (Alarcon et al. 2009; Schaufeli and Salanova 2007; Swider and Zimmerman 2010). With regard to the association between stress and language proficiency, Mousavi (2007) investigated stress among native and non-native English language teachers. In doing so, knowledge of English turned out to be the most significant difference between these two groups of teachers. Moreover, communicative language teaching 
(CLT) was regarded as challenging for half of non-native teachers because they were not certain about their language competence.

As discussed in previous sections, few studies have addressed the role of non-native EFL teachers' target language proficiency in their experience of stress and ultimately burnout (Akbari and Eghtesadi 2017; Khani and Mirzaee 2014). For example, Khani and Mirzaee (2014) conducted a study on the role of self-efficacy, contextual factors, and stressors in teacher burnout in Iranian EFL context. Discussing the results of their study, they argue that subject knowledge and language proficiency can make teachers more stressful to the negative effects of contextual factors which can ultimately expose them to psychological strain of burnout. In another study conducted recently, Akbari and Eghtesadi (2017) investigated burnout coping strategies of Iranian EFL teachers within a qualitative research methodology. Correspondingly, extending linguistic knowledge and developing language proficiency were found as one of the important burnout coping strategies used by the teachers who were not suffering from a burnout phenomenon. However, to the best knowledge of the researchers, no study has directly been conducted yet to investigate the contribution of non-native EFL teachers' target language proficiency, as a personal resource, to their burnout experience by adopting a quantitative research methodology. Accordingly, the current study endeavors to fill this gap in the EFL education and literature by exploring the association between EFL teachers' language proficiency and three aspects of burnout.

\section{Method}

\section{Participants}

The participants of this study were 110 Iranian EFL teachers who were teaching at private language institutes in Tehran and Ardabil, two cities in Iran. Unlike English language teaching in public schools, private language institutes in Iran focus more on communicative-based activities and teachers are supposed to avoid from using students' first language and are employed temporarily (Pishghadam et al. 2014). All the participants were native speakers of Persian and they learned English as a foreign language in Iran. Convenience sampling was used in order to gather the data. In other words, from the entire population of teachers who were teaching English at different language institutes, those who were available and eager took part in the study. Participants were both females $(n=86)$ and males $(n=24)$. Teachers' age ranged from 20 to 49 years old $(M=29.41)$. Among the participants, $45.5 \%(n=50)$ had less than 5 years of experience, $44.5 \%(n=49)$ had between 5 and 10 years of experience, and $10 \%$ $(n=11)$ had more than 10 years of experience. Of the participants, $33.6 \%(n=37)$ of the teachers were teaching at an elementary level, $45.4 \%(n=50)$ of participants were teaching at an intermediate level, 2.7\% ( $n=3)$ of participants were teaching at an advanced level, $10.9 \%(n=12)$ of participants were teaching at both elementary and intermediate levels, $6.4 \%(n=7)$ of participants were teaching at the elementary, intermediate, and advanced levels, and $0.9 \%(n=1)$ of participants were teaching at intermediate and advanced levels. Concerning the teachers' major, $76.4 \%(n=84)$ of the participants held English-related academic credentials (Teaching, Literature, and Translation), while 23.6\% $(n=26)$ of the participants' academic degrees were not connected with English-related fields. With respect to the educational degree of participants, $77.3 \%(n=85)$ of participants had BA 
degree, 20.9\% $(n=23)$ of teachers held MA degree, and 1.8\% $(n=2)$ of participants had $\mathrm{PhD}$ degree. All participants were informed of the purpose of data collection.

\section{Instruments}

In order to gather the data, the researchers used a survey consisting of three sections. The first section aimed at collecting participants' demographic information (gender, age, years of experience, level of teaching, degree of education, and field of study). The second section included Iranian EFL Teacher Self-report of Language Proficiency (Eslami and Fatahi 2008). The third section of the survey comprised Maslach Burnout Inventory - Educator Survey (MBI-ES) (Maslach et al. 1996) (see Additional file 1).

The MBI-ES consists of 22 items which assess the three burnout dimensions of emotional exhaustion (EE), depersonalization (DP), and personal accomplishment (PA). Accordingly, EE was measured by nine items, DP was gauged by five items, and PA was assessed by eight items. It has a 7-point frequency rating scale varying from (0) "never" to (6) "everyday". Scholars have argued that all three subscales of burnout cannot be added up to a single measure (Byrne 1994; Lee and Ashforth 1996). The reliability coefficient of each of the subscales of EE, DP, and PA turned out to be 0.88, 0.73, and 0.94 respectively by employing Cronbach alpha test of reliability.

EFL teachers' target language proficiency was measured by self-assessment because self-assessments are effective and relatively easy to administer (Butler 2004). In doing so, Iranian EFL Teacher Self-report of Language Proficiency (Eslami and Fatahi 2008) which is based on Chacón (2005) and Butler (2004) scales was used. The instrument comprises 12 items on a 5-point Likert-type scale ranging from (1) "strongly disagree" to (5) "strongly agree". The construct of language proficiency in the current study was oriented toward the four subskills of speaking, listening, writing, and reading because EFL teachers are required to employ CLT in classes which needs teachers who can speak, listen, write, and read in English with functional competency in communicating across the skills of language (Savignon 1983, 2002). The scale measures the four skills and its reliability turned out to be 0.85 as computed by Cronbach alpha coefficient (Eslami and Fatahi 2008). In the present study, the Cronbach alpha reliability coefficient was estimated to be 0.91 . However, the reliability for Speaking, Listening, Writing, and Reading subscales turned out to be $0.91,0.91,0.67$, and 0.71 respectively.

\section{Data collection and analysis}

First, 125 surveys were distributed in the form of hard copies and email attachments. One hundred twenty copies were returned, which were then reduced to 110 copies after discarding 10 surveys due to incomplete or careless answers. All the responses were coded and fed into SPSS 22 . As the preliminary stage of data analysis, the reliability of responses was checked by using Cronbach alpha coefficient of reliability. Accordingly, it has been found that all the variables enjoy a relatively high internal consistency (see previous sections). Next, normality assumption was tested by checking skewness and kurtosis values. Since depersonalization variable compared with other variables had more deviations from normality (skewness $=0.98$ and kurtosis $=0.48$ ), square root transformation was applied to improve the situation and to make it near normally distributed. In doing so, skewness and kurtosis values became -0.23 and -0.08 
respectively. Hence, the analysis was conducted using this new variable. Focusing on the first research question, Spearman rank-order coefficient of correlation was run to find the correlations between the language proficiency and three aspects of burnout. Prior to employing multiple regression to disclose the power of proficiency subskills in predicting each of the burnout aspects (the second research question), bivariate correlational analysis was conducted for all variables in order to test whether the assumption of multicollinearity was satisfied (Table 3). As Table 3 illustrates, the multicollinearity assumption was not violated since the variables were correlated less than 0.9 (Pallant 2001).

\section{Results and discussion}

To begin with, Table 1 reveals the descriptive statistics for the total score and the subscales of SLPS (Self-Perceived Language Proficiency Scale) and MBI-ES.

\section{The relationship between language proficiency and burnout dimensions}

Concentrating on the first research question, Table 2 illustrates the results of the correlational analysis for the relationship between teachers' self-assessment of language proficiency and their experience of three aspects of burnout.

As Table 2 indicates, language proficiency had significant and negative correlation with emotional exhaustion dimension of burnout $\left(r_{s}=-0.65, p^{<} 0.01\right)$. It means that English language teachers who have more personal resources, in this case English language proficiency, feel less fatigued and depleted than their less proficient colleagues. With regard to depersonalization dimension of burnout, it has been found that language proficiency had a small but significant negative relationship with this dimension of burnout $\left(r_{s}=-0.29, p^{<} 0.01\right)$. That is, teachers who are less proficient in English develop more negative feelings and cynical attitudes toward their students and their job. Concerned with the personal accomplishment dimension, the researcher found a significant positive relationship between this dimension and language proficiency of EFL teachers $\left(r_{s}=0.66, p<0.01\right)$. It implies that, English teachers who possess high language proficiency consider themselves more effective and competent in their teaching profession. Conversely, those teachers who have inappropriate language proficiency regard themselves as ineffective and incompetent in their job.

Table 1 Descriptive statistics for SLPS and MBI-ES

\begin{tabular}{lllll}
\hline & Mean & SD & Skewness (SE) & Kurtosis (SE) \\
\hline SLPS & 40.40 & 9.33 & $0.07(0.23)$ & $-0.99(0.45)$ \\
Speaking & 9.89 & 3.33 & $-0.29(0.23)$ & $-1.15(0.45)$ \\
Listening & 9.11 & 3.45 & $-0.23(0.23)$ & $-1.00(0.45)$ \\
Writing & 9.79 & 2.34 & $0.36(0.23)$ & $-0.65(0.45)$ \\
Reading & 11.60 & 1.88 & $-0.70(0.23)$ & $1.67(0.45)$ \\
Emotional exhaustion & 23.87 & 11.70 & $-0.03(0.23)$ & $-1.17(0.45)$ \\
Depersonalization & 2.41 & 1.15 & $-0.23(0.23)$ & $-0.08(0.45)$ \\
Personal accomplishment & 30.42 & 12.75 & $-0.49(0.23)$ & $-1.19(0.45)$ \\
\hline
\end{tabular}

$S D$ standard deviation, SE standard error 
Table 2 Correlations between the proficiency and burnout dimensions

\begin{tabular}{|c|c|c|c|}
\hline & Emotional exhaustion & Depersonalization & Personal accomplishment \\
\hline Proficiency & $-0.65^{* *}$ & $-0.29^{* *}$ & $0.66^{* *}$ \\
\hline
\end{tabular}

Prediction of burnout dimensions from the language proficiency subskills

Table 3 presents the correlations between the four subskills of language proficiency and three dimensions of burnout.

\section{Prediction of emotional exhaustion}

Table 4 reveals that $R^{2}$ equals 0.467 . In other words, $46.7 \%$ of the variance in the dependent variable (emotional exhaustion) is explained by the model which includes the independent variables of speaking, listening, writing, and reading.

Concerned with the evaluation of each of the subskills of English language proficiency, Table 5 shows which of the subskills in the model contributed to the prediction of the emotional exhaustion dimension of burnout. Accordingly, it shows that the beta value of writing (beta $=-0.259, p<0.05$ ) subskill was the largest negative beta coefficient. In other words, it means that having a low score on the writing subscale of language proficiency is the best predictor of the emotional exhaustion dimension of burnout. That is, the teachers who are less competent in the writing subskill are probably expected to become more emotionally exhausted during their teaching compared with their more proficient counterparts.

\section{Prediction of depersonalization}

With regard to the contribution of the language subskills to the depersonalization dimension of burnout, Table 6 illustrates that $R^{2}$ equals 0.159 . In other words, $15.9 \%$ of the variance in the dependent variable (depersonalization) is explained by the model which includes the independent variables of the speaking, listening, writing, and reading subskills of language proficiency.

Table 7 illustrates which of the language proficiency subskills in the model best contributed to the prediction of the depersonalization dimension of burnout. Accordingly, it shows that the beta value (beta $=-0.545, p^{<} 0.05$ ) of the speaking subskill is the largest negative beta coefficient. Thus, having a low score on the speaking subscale of language proficiency is the best predictor of the depersonalization dimension of

Table 3 Correlations between the language proficiency subskills and burnout dimensions

\begin{tabular}{|c|c|c|c|c|c|c|c|}
\hline & Speaking & Listening & Writing & Reading & $\mathrm{EE}$ & $\mathrm{DP}$ & $\overline{P A}$ \\
\hline \multicolumn{8}{|l|}{ Speaking } \\
\hline Listening & $0.86^{* *}$ & & & & & & \\
\hline Writing & $0.69^{* *}$ & $0.75^{* *}$ & & & & & \\
\hline Reading & $0.28^{* *}$ & $0.33^{* *}$ & $0.45^{* *}$ & & & & \\
\hline $\mathrm{EE}$ & $-0.62^{* *}$ & $-0.65^{* *}$ & $-0.59^{* *}$ & $-0.20^{*}$ & & & \\
\hline DP & $-0.38^{* *}$ & $-0.28^{* *}$ & $-0.23^{*}$ & -0.05 & $0.46^{* *}$ & & \\
\hline PA & $0.65^{* *}$ & $0.65^{* *}$ & $0.51^{* *}$ & $0.31^{* *}$ & $0.81^{* *}$ & $-0.35^{* *}$ & \\
\hline
\end{tabular}

**Correlation is significant at the 0.01 level (two-tailed). *Correlation is significant at the 0.05 level (two-tailed). $E E$ emotional exhaustion, DP depersonalization, $P A$ personal accomplishment 
Table 4 Model summary for the language proficiency subskills as predictors of emotional exhaustion

\begin{tabular}{lllcc}
\hline Model & $R$ & $R^{2}$ & Adjusted $R^{2}$ & Std. error of the estimate \\
\hline 1 & 0.683 & 0.467 & 0.447 & 8.707 \\
\hline Predictors: (constant) speaking listening, writing, reading & &
\end{tabular}

Predictors: (constant) speaking, listening, writing, reading

burnout. In other words, those teachers who are less proficient in the speaking subskill might show more negative attitudes toward their students and their job than those teachers who are more competent.

\section{Prediction of personal accomplishment}

With respect to the contribution of the language subskills to the personal accomplishment dimension of burnout, Table 8 presents that $R^{2}$ equals 0.470 . In other words, $47 \%$ of the variance in the dependent variable (personal accomplishment) is explained by the model which includes the four subskills of language proficiency as independent variables.

More specifically, Table 9 illustrates which of the language proficiency subskills in the model makes a unique contribution to the prediction of the personal accomplishment dimension of burnout. To this end, it shows that the beta value of the speaking (beta $=0.366, p^{<} 0.05$ ) and listening (beta $=0.327, p^{<0.05)}$ ) subskills are the largest beta coefficients. Hence, obtaining high scores on the listening and speaking subskills of language proficiency can best predict personal accomplishment. It indicates that EFL teachers who are more capable in the listening and speaking subskills may more experience the personal accomplishment aspect of burnout.

Concerned with the first research question, low scores in perceived language proficiency was in association with high scores in the emotional exhaustion and depersonalization aspects and with low scores in the personal accomplishment aspect of burnout. This finding indicates that those teachers who deemed their language proficiency as insufficient may experience more emotional exhaustion, depersonalization, and reduced sense of efficacy in their teaching. This finding may be explained by those researchers' findings who put emphasis on the inappropriate language proficiency level of non-native EFL teachers (e.g., Butler 2004; Chen and Goh 2011). This finding can be explained by the notion that burnout occurs because of misfit between job demands and individual resources to overcome those demands (Maslach 2003; Maslach et al. 2001). The finding observed in this study may confirm the idea of Khani and Mirzaee (2014) who discuss that EFL teachers are supposed to

Table $\mathbf{5}$ The results of multiple regression analysis for the language proficiency subskills and emotional exhaustion

\begin{tabular}{llllll}
\hline & \multicolumn{2}{l}{ Unstandardized coefficients } & & \multicolumn{2}{c}{ Standardized coefficients } \\
\cline { 2 - 3 } & $B$ & Std. error & & Beta & Sig. \\
\hline Speaking & -0.723 & 0.507 & & -0.206 & 0.157 \\
Listening & -1.030 & 0.530 & & -0.304 & 0.055 \\
Writing & -1.296 & 0.580 & & -0.259 & 0.027 \\
Reading & 0.479 & 0.499 & & 0.077 & 0.339 \\
\hline
\end{tabular}

Dependent variable: emotional exhaustion 
Table 6 Model summary for the language proficiency subskills as predictors of depersonalization

\begin{tabular}{lllcc}
\hline Model & $R$ & $R^{2}$ & Adjusted $R^{2}$ & Std. error of the estimate \\
\hline 1 & 0.399 & 0.159 & 0.127 & 1.081 \\
\hline Predictors: (constant), speaking, listening, writing, reading & &
\end{tabular}

speak English fluently and teach textbooks which are written by native speakers and these can make them more stressful in coping with student misbehavior and time limitation which can ultimately expose them to the experience of burnout. The finding is also in line with Akbari and Eghtesadi's (2017) findings which revealed the association between EFL teachers' linguistic knowledge development and burnout avoidance. More specifically, they observed that developing competence in different aspects of the English language was one of the significant coping strategies of those EFL teachers who were not suffering from burnout. Focusing on the association between individual resources and burnout, the present finding seems to be in agreement with the findings of Lauerman and König (2016) who investigated the role of personal resources as protective factors against teacher burnout. As mentioned earlier, they found that teachers' self-efficacy and general pedagogical knowledge, as personal resources, can negatively predict burnout among teachers. The findings of this study confirm the results obtained by Kulavuz-Onal and Tatar (2017) who found that professional knowledge development can decrease EFL teachers' burnout. As discussed earlier, this finding can also be explained by both the association of teachers' inadequate foreign language proficiency to anxiety (e.g., Horwitz 1996) and the relation of anxiety to burnout syndrome (e.g., Alarcon et al. 2009; Schaufeli and Salanova 2007).

The only best prediction of high scores in emotional exhaustion was made by low scores in perceived writing competency. This result implies that the participant EFL teachers consider themselves less proficient in the writing subskill. A possible reason for this finding might be the complexities of written language and the challenges of becoming an effective writing teacher (Brown 2001) which can expose EFL teachers more to emotional exhaustion as the stress aspect of burnout (Maslach et al. 2001). Also, writing skill is perceived by many as the most demanding skill. The finding of the current study is contrary to the findings of Chacón (2005) who found writing as a developed skill among EFL teachers in Venezuela. This is also in sharp contrast with Chen and Goh (2011) who argue that teachers usually perceive themselves competent in the writing skill. However, this finding is in agreement with Atay and Kurt's (2006) finding which indicated that most pre-service EFL teachers who participated in their study had difficulty and experience anxiety in second language writing. This finding is also consistent with Butler (2004) who found that EFL teachers perceive themselves less

Table 7 The results of multiple regression analysis for the language proficiency subskills and depersonalization

\begin{tabular}{llllll}
\hline & \multicolumn{2}{l}{ Unstandardized coefficients } & & \multicolumn{2}{c}{ Standardized coefficients } \\
\cline { 2 - 3 } & $B$ & Std. error & & Beta & Sig. \\
\hline Speaking & -0.189 & 0.063 & & -0.545 & 0.003 \\
Listening & 0.057 & 0.066 & & 0.169 & 0.391 \\
Writing & 0.000 & 0.072 & & -0.001 & 0.997 \\
Reading & 0.026 & 0.062 & 0.042 & 0.676 \\
\hline
\end{tabular}

Dependent variable: depersonalization 
Table 8 Model summary for the language proficiency subskills as predictors of personal accomplishment

\begin{tabular}{lllcc}
\hline Model & $R$ & $R^{2}$ & Adjusted $R^{2}$ & Std. error of the estimate \\
\hline 1 & 0.685 & 0.470 & 0.449 & 9.467 \\
\hline Predictors: (constant) & & &
\end{tabular}

Predictors: (constant) speaking, listening, writing, reading

proficient in productive skills (speaking and writing) than in receptive ones (listening and reading). Focusing on the contribution of teachers' individual resources to the emotional exhaustion dimension of burnout, this finding is consistent with those of other studies which emphasized that individual resources (self-efficacy and pedagogical knowledge) are negatively related to emotional exhaustion (Lauerman and König 2016; Skaalvik and Skaalvik 2010).

Focusing on the prediction of the depersonalization aspect of burnout, it has been found that low scores in the self-assessed speaking subskill is the only best predictor of depersonalization. It is quite logical to infer that teachers who consider themselves less proficient in speaking a foreign language may regard speaking as challenging and stressful and consequently become indifferent to and develop negative attitudes toward their job and students (Maslach 1982; Maslach et al. 2001). This finding indicates that the participants of the study regard their speaking proficiency as inappropriate which might be justifiable due to focus of ELT in Iran which is a more theory-oriented rather than product-oriented system (Pishghadam et al. 2014). This is in line with the findings of Chen and Goh (2011) who found that EFL teachers in China regard their oral English fluency as inadequate. Another possible explanation for this is that "[p]eople engage in tasks in which they feel competent and confident and avoid those in which they do not" (Pajares 1996, p. 544). This finding is also in agreement with the findings of previous researchers who emphasized the contribution of individual resources to depersonalization aspect of burnout (e.g., Kulavuz-Onal and Tatar 2017; Lauerman and König 2016; Skaalvik and Skaalvik 2010).

Personal accomplishment dimension of burnout was significantly predicted by teachers' perceived speaking and listening abilities. It is quite justifiable that those teachers who regard themselves more competent in the speaking and listening subskills of language proficiency, experience more feelings of competence and achievement at work (Maslach et al. 2001) and vice versa. Focusing on speaking, this finding confirms the idea of Harmer (2001) who emphasizes teacher talking quality for effective English language teaching and learning. With regard to the listening subskill, the finding provides evidence to support that listening activity is difficult for teachers because they cannot perceive when students experience discomfort during the activity (Vogely 1999). Concerned

Table 9 The results of multiple regression analysis for the language proficiency subskills and personal accomplishment

\begin{tabular}{|c|c|c|c|c|}
\hline & \multicolumn{2}{|c|}{ Unstandardized coefficients } & \multicolumn{2}{|c|}{ Standardized coefficients } \\
\hline & $B$ & Std. error & Beta & Sig. \\
\hline Speaking & 1.398 & 0.551 & 0.366 & 0.013 \\
\hline Listening & 1.208 & 0.576 & 0.327 & 0.039 \\
\hline Writing & -0.196 & 0.630 & -0.036 & 0.756 \\
\hline Reading & 0.755 & 0.542 & 0.111 & 0.167 \\
\hline
\end{tabular}

Dependent variable: personal accomplishment 
with the relation between personal accomplishment and efficacy of teachers (Byrne 1999; Teven 2007), this finding can be explained in two ways. First, research indicated relations between EFL teachers' self-reported language proficiency and their self-efficacy beliefs (e.g., Eslami and Fatahi 2008; Chacón 2005). Second, several researchers have claimed about the contribution of teachers' self-efficacy beliefs to feelings of personal accomplishment (e.g., Skaalvik and Skaalvik 2007). Hence, it seems possible to hypothesize that the prediction of personal accomplishment by the speaking and listening subskills of language proficiency is due to the effect of teaching efficacy directly or indirectly. However, more research on this topic needs to be undertaken before the association among language proficiency, self-efficacy, and personal accomplishment is more clearly understood.

In this study, the reading subskill was not considered as a challenging skill and did not make a unique contribution to any dimensions of burnout. This can be attributed to the nature of the reading skill which is more practiced, and most language courses focus on reading more than other skills. This finding can be quite understandable due to other researchers' findings which indicated that EFL teachers perceive themselves more proficient in the reading subskill (Chacón 2005; Eslami and Fatahi 2008).

\section{Conclusion}

To the best knowledge of the authors, the present study was the first attempt at investigating the relationship between non-native EFL teachers' self-assessed language proficiency and their experience of three aspects of burnout directly through a quantitative research methodology. With regard to the first research question, it has been found that language proficiency has a significant negative relationship with emotional exhaustion and depersonalization dimensions of burnout. With regard to relation between personal accomplishment and language proficiency, a significant positive relationship was found. Concerned with the second research question, emotional exhaustion was best predicted by the writing subskill of proficiency. Furthermore, it has been found that the speaking subskill of language proficiency can make a unique contribution to the depersonalization aspect. Eventually, the speaking and listening subskills turned out to be the best predictors of the personal accomplishment dimension of burnout.

In the light of the current findings, a few pedagogical implications can be proposed for EFL education and teacher educators. First, the findings of the study emphasize that those who recruit EFL teachers need to pay close attention to language proficiency of teachers not only for maximizing teachers' efficacy of teaching but also for preventing teachers' from experiencing burnout. Second, administrators and teacher educators should create and provide opportunities (e.g., summer workshops, study-abroad programs, and university courses) for non-native EFL teachers in order to help these teachers to maintain and improve their language proficiency. These programs may also help teachers increase their engagement, as an antithesis of burnout (Maslach et al. 2001), and efficacy and ultimately reduce their experience of burnout.

The findings of the current study must be treated with caution because of some limitations. First, the present study's findings are generally correlational which limits causal interpretations. Second, although our data has met the multicollinearity assumption which indicates suitability for doing parametric multiple regression analysis, its deviation from normality assumption is another limitation. Third, the findings are 
based on the data collected in Iranian context as an EFL context and the participants of the current study are limited to those EFL teachers who teach in private language institutes in Iran which are different from high schools and universities with regard to educational objectives and atmosphere. Fourth, the data for measuring language proficiency has been collected by utilizing a self-assessment tool which implies certain built-in limitations.

It is recommended that future research be undertaken in the following areas: First, it would be interesting to replicate the study by adopting a mixed-method design or using other assessment tools in order to measure the language proficiency of participants. Second, future research can be done with those teachers who teach in other ELT educational contexts (e.g., ESL contexts) due to some probable differences in teachers' language competencies and abilities. It is further recommended that future research be undertaken based on the limitations of the study.

\section{Additional file}

Additional file 1: Maslach Burnout Inventory - Educator Survey (DOCX 14 kb)

\section{Abbreviations}

CLT: Communicative language teaching; DP: Depersonalization; EE: Emotional exhaustion; EFL: English as a foreign language; ESL: English as a second language; MBI-ES: Maslach Burnout Inventory - Educator Survey; NNEST: Non-native English-speaking teacher; PA: Personal accomplishment

\section{Acknowledgements}

Not applicable

Funding

No funding was received from any specific funding agencies.

\section{Availability of data and materials}

The datasets used and/or analyzed during the current study are available from the corresponding author on reasonable request.

\section{Authors' contributions}

To conduct this study, AN and ZB worked collaboratively throughout all stages of research. Both authors read and approved the final manuscript.

\section{Competing interests}

The authors declare that they have no competing interests.

\section{Publisher's Note}

Springer Nature remains neutral with regard to jurisdictional claims in published maps and institutional affiliations.

Received: 19 December 2018 Accepted: 14 February 2019

Published online: 28 February 2019

\section{References}

Akbari, R. (2008). Post-method discourse and practice. TESOL Quarterly, 42(4), 641-652.

Akbari, R., \& Eghtesadi, A. R. (2017). Burnout coping strategies among Iranian EFL teachers. Applied Research on English Language, 6, 179-192.

Akbari, R., \& Tavassoli, K. (2011). Teacher efficacy, burnout, teaching style, and emotional intelligence: possible relationships and differences. Iranian Journal of Applied Linguistics, 14(2), 31-61.

Alarcon, G., Eschleman, K. J., \& Bowling, N. A. (2009). Relationships between personality variables and burnout: a metaanalysis. Work Stress, 23, 244-263.

Andrews, S. (2007). Teacher language awareness. Cambridge: Cambridge University Press.

Atay, D., \& Kurt, G. (2006). Prospective teachers and L2 writing anxiety. Asian EFL Journal, 8(4) Retrieved from http://www. asian-efl-journal.com/December_2006_EBook.pdf\#page=100.

Bachman, L. F., \& Palmer, A. S. (1996). Language testing in practice. Oxford: Oxford University Press.

Bekleyen, N. (2009). Helping teachers become better English students: causes, effects and coping strategies for foreign language listening anxiety. System, 37, 664-675.

Brain, G. (Ed.). (1999). Non-native educators in English language teaching. New Jersey: Lawrence Erlbaum. 
Braine, G. (2010). Nonnative speaker English teachers: research, pedagogy, and professional growth. New York, NY: Routledge.

Brown, H. D. (2001). Teaching by principles: an interactive approach to language pedagogy (2nd ed.). New York, NY: Longman.

Butler, Y. G. (2004). What level of English proficiency do elementary school teachers need to attain to teach EFL? Case studies from Korea, Taiwan, and Japan. TESOL Quarterly, 38(2), 245-278.

Byrne, B. (1999). The nomological network of teacher burnout: a literature review and empirically validated model. In R. Vandenberghe \& A. M. Huberman (Eds.), Understanding and preventing teacher burnout: a sourcebook of international research and practice (pp. 15-37). Cambridge: Cambridge University Press.

Byrne, B. M. (1994). Burnout: testing for the validity, replication, and the invariance of the causal structure across elementary, intermediate, and secondary teachers. American Educational Research Journal, 31, 645-673.

Canh, L., \& Renandya, W. A. (2017). Teachers' English proficiency and classroom language use: a conversation analysis study. RELC Journal, 48(1), 67-81

Chacón, C. (2005). Teachers' perceived efficacy among English as a foreign language teachers in middle schools in Venezuela. Teaching and Teacher Education, 21, 257-272

Chen, Z., \& Goh, C. (2011). Teaching oral English in higher education: challenges to EFL teachers. Teaching in Higher Education, 16, 333-345.

Cheng, L., \& Wang, H. (2004). Understanding professional challenges faced by Chinese teachers of English. TESL-EJ, 7(4) Retrieved from https://files.eric.ed.gov/fulltext/EJ1068090.pdf.

Chiron, B., Michinov, E., Olivier-Chiron, E., Laffon, M., \& Rusch, E. (2010). Job satisfaction, life satisfaction and burnout in French anaesthetists. Journal of Health Psychology, 15, 948-958

Choi, E., \& Lee, J. (2016). Investigating the relationship of target language proficiency and self-efficacy among nonnative EFL teachers. System, 58, 49-63.

Chomsky, N. (1965). Aspects of the theory of syntax. Cambridge: MIT Press.

Dicke, T., Parker, P. D., Holzberger, D., Kunina-Habenicht, O., Kunter, M., \& Leutner, D. (2015). Beginning teachers' efficacy and emotional exhaustion: latent changes, reciprocity, and the influence of professional knowledge. Contemporary Educational Psychology, 41(1), 62-72.

Dicke, T., Parker, P. D., Marsh, H. W., Kunter, M., Schmeck, A., \& Leutner, D. (2014). Self-efficacy in classroom management, classroom disturbances, and emotional exhaustion: a moderated mediation analysis of teacher candidates. Journal of Educational Psychology, 106(2), 569-583.

Durr, T., Chang, M. L., \& Carson, R. L. (2014). Curbing teacher burnout. In P. W. Richardson, S. A. Karabenick, \& H. M. G. Watt (Eds.), Teacher motivation: implications for theory and practice (pp. 198-213). U.S.: Routledge/Taylor \& Francis.

Elder, C., \& Kim, S. (2014). Assessing teachers' language proficiency. In A. J. Kunnan (Ed.), The companion to language assessment. Chichester: John Wiley and Sons, Inc..

Ellis, R. (2005). Principles of instructed second language learning. System, 33(2), 209-224

Eslami, Z., \& Fatahi, A. (2008). Teachers' sense of self-efficacy, English proficiency, and instructional strategies: a study of nonnative EFL teachers in Iran. TESL-J, 11(4), n4.

Farrell, T. S., \& Richards, J. C. (2007). Teachers' language proficiency. In T. S. Farrell (Ed.), Reflective language teaching: from research to practice (pp. 55-66). London: Continuum.

Freudenberger, H. J. (1974). Staff burnout. Journal of Social Issues, 30(1), 159-166.

Ghanizadeh, A., \& Ghonsooly, B. (2014). A tripartite model of EFL teacher attributions, burnout, and self-regulation: toward the prospects of effective teaching. Educational Research in Policy and Practice, 13, 145-166.

Grayson, J. L., \& Alvarez, H. K. (2008). School climate factors relating to teacher burnout: a mediator model. Teaching and Teacher Education, 24, 1349-1363.

Hakanen, J. J., Bakker, A. B., \& Schaufeli, W. B. (2006). Burnout and work engagement among teachers. Journal of School Psychology, 43, 495-513.

Harmer, J. (2001). The practice of English language teaching (4rd ed.). Edinburgh: Pearson Education Limited.

Hiver, P. (2013). The interplay of possible language teacher selves in professional development choices. Language Teaching Research, 17, 210-227.

Horwitz, E. K. (1996). Even teachers get the blues: recognizing and alleviating non-native teachers feelings of foreign language anxiety. Foreign Language Annals, 29, 365-372.

Hymes, D. H. (1972). On communicative competence. In J. B. Pride \& J. Holmes (Eds.), Sociolinguistics: selected readings (pp. 269-293). Harmondsworth: Penguin.

Jennett, H. K., Harris, S. L., \& Mesibov, G. B. (2003). Commitment to philosophy, teacher efficacy, and burnout among teachers of children with autism. Journal of Autism and Developmental Disorders, 33, 583-593.

Khani, R., \& Mirzaee, A. (2014). How do self-efficacy, contextual variables and stressors affect teacher burnout in an EFL context? Educational Psychology: An International Journal of Experimental Educational Psychology, 35, 93-109.

Kim, S., \& Elder, C. (2008). Target language use in foreign language classrooms: practices and perceptions of native speaker teachers. Lang Cult Curric, 21(2), 167-185.

Kinman, G., Wray, S., \& Strange, C. (2011). Emotional labour, burnout and job satisfaction in UK teachers: the role of workplace social support. Educational Psychology, 31, 843-856.

Klusmann, U., Kunter, M., Trautwein, U., Lüdtke, O., \& Baumert, J. (2008). Teachers' occupational well-being and quality of instruction: the important role of self-regulatory patterns. Journal of Educational Psychology, 100(3), 702-715.

Kokkinos, C. M. (2007). Job stressors, personality and burnout in primary school teachers. British Journal of Educational Psychology, 77, 229-243

Kulavuz-Onal, D., \& Tatar, S. (2017). Teacher burnout and participation in professional learning activities: perspectives from university English language instructors in Turkey. Journal of Language and Linguistic Studies, 13(1), 283-303.

Lantolf, J., \& Frawley, W. (1988). Proficiency: understanding the construct. Studies in Second Language Acquisition, 10(2), $181-195$.

Lauerman, F., \& König, J. (2016). Teachers' professional competence and well-being: understanding the links between general pedagogical knowledge, self-efficacy and burnout. Learning and Instruction, 45, 9-19.

Lee, R. T., \& Ashforth, B. E. (1996). A meta-analytic examination of the correlates of the three dimensions of job burnout. Journal of Applies Psychology, 81, 123-133. 
Llurda, E. (Ed.). (2005). Non-native language teachers: perceptions, challenges and contributions to the profession. New York: Springer.

Maslach, C. (1982). Burnout, the cost of caring. Englewood Cliffs, NJ: Prentice Hall.

Maslach, C. (2003). Job burnout: new directions in research and intervention. Current Directions in Psychological Strain, 12, $189-192$.

Maslach, C., \& Jackson, S. E. (1981). The measurement of experienced burnout. Journal of Occupational Behavior, 2, 99-113.

Maslach, C., \& Jackson, S. E. (1986). MBl: Maslach Burnout Inventory manual (2nd edition). Palo Alto: Consulting Psychologists Press.

Maslach, C., Jackson, S. E., \& Leiter, M. P. (1996). MBl: the Maslach Burnout Inventory manual (3rd ed.). Palo Alto: Consulting Psychologists Press.

Maslach, C., \& Leiter, M. P. (1999). Teacher burnout: a research agenda. In R. Vandenberghe \& A. M. Huberman (Eds.), Understanding and preventing teacher burnout: a sourcebook of international research and practice (pp. 295-303). Cambridge: Cambridge Univ. Press.

Maslach, C., Schaufeli, W. B., \& Leiter, M. (2001). Job burnout. Annual Review of Psychology, 52(1), 397-422.

Mousavi, E. S. (2007). Exploring 'teacher stress' in non-native and native teachers of EFL. ELTED, 10, 33-41.

Nakata, Y. (2010). Improving the classroom language proficiency of non-native teachers of English: what and how? RELC Journal, 41(1), 76-90.

Pajares, F. (1996). Self-efficacy beliefs in academic settings. Review of Educational Research, 66, 543-578.

Pallant, J. (2001). SPSS survival manual: a step by step guide to data analysis using IBM SPSS (6th ed.). New York, NY: McGrawHill Education.

Pines, A., \& Aronson, E. (1988). Career burnout: causes and cures. New York: The Free Press.

Pishghadam, R., Admason, B., Sadafyan, S. S., \& Kan, F. L. F. (2014). Conceptions of assessment and teacher burnout. Assessment in Education: Principles, Policy \& Practice, 21(1), 34-51.

Reves, T., \& Medgyes, P. (1994). The non-native English speaking EFL/ESL teacher's self-image: an international survey. System, 22(3), 353-367.

Richards, H., Conway, C., Roskvist, A., \& Harvey, S. (2013). Foreign language teachers' language proficiency and their language teaching practice. The Language Learning Journal, 41(2), 231-246.

Richards, J. C. (2015). Key issues in lanquage teaching. Cambridge: Cambridge University Press.

Richards, J. C. (2017). Teaching English through English: proficiency, pedagogy and performance. RELC Journal, 1-24.

Samimy, K., \& Brutt-Griffler, J. (1999). To be a native or nonnative speaker: perceptions of nonnative speaking students in a graduate TESOL program. In G. Braine (Ed.), Non-native educators in English language teaching (pp. 127-144). Mahwah: Erlbaum.

Savignon, S. (1983). Communicative competence: theory and classroom practice. Reading, MA: Addison-Wesley.

Savignon, S. J. (Ed.). (2002). Interpreting communicative language teaching: contexts and concerns in teacher education. New Haven: Yale University Press.

Schaufeli, W. B., \& Salanova, M. (2007). Efficacy or inefficacy, that's the question: burnout and work engagement, and their relationships with efficacy beliefs. Anxiety, Stress \& Coping, 20, 177-196.

Schwarzer, R., \& Hallum, S. (2008). Perceived teacher self-efficacy as a predictor of job stress and burnout. Applied Psychology: An International Review, 57(Suppl. 1), 152-171.

Skaalvik, E. M., \& Skaalvik, S. (2007). Dimensions of teacher self-efficacy and relations with strain factors, perceived collective teacher efficacy, and teacher burnout. Journal of Educational Psychology, 99, 611-625.

Skaalvik, E. M., \& Skaalvik, S. (2009). Does school context matter? Relations with teacher burnout and job satisfaction. Teaching and Teacher Education, 25, 518-524.

Skaalvik, E. M., \& Skaalvik, S. (2010). Teacher self-efficacy and teacher burnout: a study of relations. Teaching and Teacher Education, 26, 1059-1069.

Swider, B. W., \& Zimmerman, R. D. (2010). Born to burnout: a meta-analytic path model of personality, job burnout, and work outcomes. Journal of Vocational Behavior, 76, 487-506.

Teven, J. (2007). Teacher temperament: correlates with teacher caring, burnout, and organizational outcomes. Communication Education, 56, 382-400.

Tsang, A. (2017). EFL/ESL teachers' general language proficiency and learners' engagement. RELC Journal, 48(1), 99-113.

Vaezi, S., \& Fallah, N. (2011). The relationship between emotional intelligence and burnout among Iranian EFL teachers. Journal of Language Teaching and Research, 2(15), 1122-1129.

Vogely, A. (1999). Addressing listening comprehension anxiety. In D. J. Young (Ed.), Affect in foreign language and second language learning (pp. 105-123). New York: McGraw Hill.

\section{Submit your manuscript to a SpringerOpen ${ }^{\circ}$ journal and benefit from:}

- Convenient online submission

- Rigorous peer review

- Open access: articles freely available online

High visibility within the field

- Retaining the copyright to your article

Submit your next manuscript at $\boldsymbol{\nabla}$ springeropen.com 